\title{
Buk Kriszta
}

\section{KÉNYELMES RABSZOLGASÁG - KÉNYELMETLEN SZABADSÁG \\ Értékek jelentéskeresése korunk hétköznapi valóságreprezentációiban}

\section{DOI 10.35402/kek.2021.1.1}

\begin{abstract}
Absztrakt
Mihez kezdünk az értékekkel napjainkban megtesszük, megvesszük, megesszük őket? Iránytü, térkép, célja vagy eszköze az embernek az értékes élet? Írásomban a hétköznapjainkban megmutatkozó értékek keresésének nyomába eredek a legkülönbözőbb forrásokon keresztül. Váriné Szilágyi Ibolya Az ember, a világ és az értékek világa címü könyvét használom vezérfonalként és vetem össze megfigyeléseimmel, könyvekben, újságokban, szakfolyóiratokban megjelenő, irodalmi és tudományos cikkekben megfogalmazódó értékekkel, a Fedél Nélkül-töl, a Szombaton, Magyar Narancson át, a Kultúra és Közösségig. Kedvenc gondolkodóim, társadalomtudósok, történészek, antropológusok, filozófusok írásain keresztül próbálom megragadni, értelmezni napjaink domináns értékekeinek mibenlétét, összevetve a hagyományos vallásos értékekkel és a Maslowszükségletpiramisban gyökeredző értékekkel. Végül röviden ismertetem a multikulturális családok gyereknevelésében megmutatkozó értékelgondolását.
\end{abstract}

\footnotetext{
Abstract

Comfortable Slavery - Uncomfortable Freedom. Searching for meaning of values in the everyday representations of reality of our time

What do we do with values nowadays? Do we take them, buy, or eat them? Is life filled with values a compass, a map, purpose or tool for man? In my essay, through a variety of sources, I follow search for values that show up in our everyday lives. I use the book of Ibolya Vári-Szilágyi's Az ember, a világ és az értékek világa (Man, the World and the World of Values) as a guideline, and compare it with my own observations, values in books, newspapers and periodicals, literary and scientific articles (from Fedél Nélkül, into Szombat, through Magyar Narancs, up to Kulturra és Közösség), through the writings of my favourite thinkers, social scientists, historians, anthropologists, and philosophers, I attempt to capture and interpret the nature of today's dominant values in comparison with
}

traditional religious values and the values rooted in the Maslow pyramid of needs. Finally, I briefly describe the value consideration in raising children of multicultural families.

Minden, ami körülvesz minket - az emberi interakciók, az ismerősök posztjai, a szembejövő hírek, reklámok, a focitól a vásárlásig - így vagy úgy az értékekről szólnak, megjelenítik, közvetítik őket, azokat akarják áthangolni, használni, eladni, megvenni. Dolgozatomban arra vállalkozom, hogy a mindennapok gyakorlati valóságában megjelenő értékeket bemutassam. Váriné Szilágyi Ibolya $A z$ ember, a világ és az értékek világa címü könyvét használom vezérfonalként és vetem össze megfigyeléseimmel, könyvekben, újságokban, szakfolyóiratokban megjelenő irodalmi és tudományos cikkekben megfogalmazódó értékekkel - a Fedél Nélkül-től, a Szombaton, Magyar Narancson át, a Kultúra és Közösségig. Hónapok óta tudatosan figyelem és gyüjtöm ezeket a megnyilvánulásokat, furcsa kettősség van mindabban, amit kinyilatkoztatunk, és ami cselekedeteinken keresztül mutatkozik meg. Kedvenc gondolkodóim, társadalomtudósok, történészek, antropológusok, filozófusok írásain keresztül próbálom megragadni, értelmezni napjaink domináns értékekeinek mibenlétét, lényegét, majd röviden ismertetem a multikulturális családok gyereknevelésében megmutatkozó értékelgondolásokat. Számtalan jeles kutató dolgozott ki értékelméleteket, alkottak értékkategóriákat, tették fel a kérdést: mi is az az érték, mikor, hol, kinek és miért érték az, amit annak gondolunk. Oldalakon keresztül lehetne elmélkedni ezen ideák jelentésének mélységeiről fizikai-szellemi, egyéni-kollektív, biológiai-kulturális szinten egyaránt.

Nehéz nem onnan indítani, hogy ezek sokaságát felvázoljuk, ismertetjük, kategorizáljuk. Mégis megpróbálom ezt a kényszert most elengedni, mert sokan megtették már előttem. Írásomban egy pillanatnyi kitekintéssel a hétköznapjainkban megmutatkozó értékek keresésének nyomába eredek a legkülönbözőbb forrásokon keresztül. Mihez kezdünk az értékekkel napjainkban, megtesszük, 
megvesszük, megesszük őket? Iránytű, vagy térkép, célja vagy eszköze az embernek az értékes élet?

Sok esetben, ebben az esszében például, csak a gondolat, problémakör megfogalmazásáig jutok, valamint különböző tudományterületek információinak, axiómáinak, paradigmáinak szintetizálásával a kérdések megfogalmazásáig. Neves tudósok eszszenciális gondolatait hívom segítségül, és továbbgondolásra bocsájtom azokat.

Az értékkategóriákat spontán vagy tudatosan alkalmazó köznapi, ideológiai, művészi megnyilvánulásokban szubjektív jelentéstartalommal van dolgunk. Ez a jelentéstartalom azt fejezi ki, hogy az egyének, csoportok, társadalmak, kultúrák hogyan vonják be a meglevő társadalmi-természeti viszonyokat és feltételeket saját életvezetésükbe; milyen érzelmi-értelmi hangsúlyt és fontosságot tulajdonítanak ezeknek; mire törekednek, s hogyan látják céljaik elérésének megvalósíthatóságát. ${ }^{1}$

A posztmodernen túl vagyunk, időomlás van, minden egyszerre van jelen... és annak az ellenkezője is, elég csak körülnézni a világhálón. Bizonyos értékek eltűntek a fösodorból, bizonyos értékek túlhangsúlyosodnak, eltolódnak, még inkább átértelmeződnek, felcserélődnek, talán még el is torzulnak (pl. a barbibabává operáltatott női test, mint szépség).

Az emberélet értéke elsődlegesnek és univerzálisnak tűnik, az ember alkotta civilizáció valóságolvasatának szempontjából mindenképpen. De vajon a mindenkori természeti valóság számára is olyan értékes-e az egyes ember élete? Pláne, ha az gazdasági haszon érdekében őserdőket pusztít, vizet és levegőt szennyez és ténykedése állatfajokat sodor a kihalás szélére, rombolva ezzel a biodiverzitást, ami a természet harmonikus mủködésének feltétele.

Csepeli György Ember 2.0 címü könyvének első gondolatai közt szerepel, hogy az „Élet él és élni akar”. Az élet az élettelenből keletkezett. Minden Egy. Az élet a megmaradás, az elmúlás, az újrateremtés folyamata, melyben a gének biológiai, a mémek kulturális szinten viszik át az információt időben és térben. ${ }^{2}$

„Ugyanaz az ÉN néz ki mindenkinek a szemén"3 - fejti ki Laár András egy nagyon inspiráló internetes interjú keretében.

$\mathrm{Ez}$ az ismerethalmaz egy tudásanyag, aminek átadásához kapcsolatra van szükség és

\footnotetext{
1 Váriné 1987.

2 Csepeli 2020

3 Laár 2020.
}

együttműködésre - még a legalapvetőbb szinten is -, ami csak valamilyen rendszerben elképzelhető. „Az élő szervezetek legelső építő kövei a molekulák voltak, melyek akkor léptek az evolúció útjára, amikor együttműködtek és ezáltal képessé váltak az információ átadására" (Csepeli uo.). ${ }^{4}$

Nincs ez másként az ember és a civilizáció esetében sem. Harari azt mondja, hogy a homo sapiens azért tudott kiemelkedni az emberszabásúak világából, mert együttműködött társaival és empirikusan szerzett tudását valamilyen rendszerben tovább adta. A természeti, biológiai környezethez való alkalmazkodáson túl az együttműködés szabályainak megalkotásával és továbbadásával megteremtett egy társas, kulturális mezőt - benne az erkölcsi értékeket -, mely jelentősen megnövelte túlélési esélyeit. A beszéd képessége lehetővé tette az emberi nyelv kialakulását, az átadott ismeretek tovább bővítik a variabilitást, lehetőséget adva ezzel a múlt, a jelen, a jövő létező, lehetséges és lehetetlen megfogalmazását. ${ }^{5}$ Csepeli is utal erre a Szathmáry Eörs féle „adaptív csomag” kapcsán, melynek a nyelv éppúgy eleme, mint az előbb említett együttmúködés, azaz kooperálás, az empátia, a tanulás, tanítás képessége, mint az ember megmaradását lehetővé tevő komplex rendszer részei. ${ }^{6}$

Az emberélet, a tudás, a bizalom és együttműködés tehát alapvető és univerzális értékeknek tűnnek a közösségek életében. De vajon tényleg azok-e? Mi az értéke egy utcán fekvő hajléktalan ember életének, és mennyit ér ma egy emberi szerv, egy máj, vagy vese, mint transzplantátum?

A végtelen információ és a tudásmunkások korában érdemes megvizsgálnunk az információval való viszonyunkat. Rengeteg tudásanyag halmozódik fel percről percre a toronyház-szerű szervereken, és a „felhőben”. Igazak és hamisak, hasznosak és haszontalanok. Bölcsességre van szükség, hogy eligazodjunk köztük. Gondoljunk csak a részletesen kidolgozott összeesküvés-elméletekre, vagy a pénzért megvásárolható New Age praktikákra, melyek megvilágosodással kecsegtetnek. Érdekes lenne megvizsgálni ezek értékkoncepcióit is. Felmerül a kérdés: hol a határ a valós és valótlan között, vajon a világvallások, vagy a kapitalizmus konstrukciói mennyiben különböznek ezektől? A namíbiai sivatagban élő ember számára valószínűleg nem sokban.

\footnotetext{
4 Csepeli 2020.

5 Harari 2015.

6 Csepeli 2020.
} 
„Civilizációnk az élet értelmének, a szabadságnak, az emberiség fontosságának és halhatatlanságának káprázatos tủzijátéka. Ámítás és önámítás, de segít nekünk élni egy olyan univerzumban, amelyben ezen kívül lehetséges, hogy nincs értelme, és nincs szabadság, és az emberi lét végtelenül esendő és mulandó"

$\mathrm{Az}$ értékforgalmak azt a benyomást keltik, hogy a legáltalánosabb értékkategóriák közösek, hogy vannak általános emberi értékek. Azonban ha jobban megvizsgáljuk, kiderül, hogy különböző korokban és társadalmakban erősen eltérő az, hogy mit értenek értéken. Az értékek, mint életszervező elvek, valójában absztrakciók. ${ }^{8}$

Valaha a természeti népek, akik nem ismerték a felhalmozást, azt tartották gazdagnak, aki javaiból sokat juttatott a közösségnek, és azokat a tagokat ruházták fel hatalommal, akik a közösség érdekében sokat tettek. Aki gazdája volt valaminek, vagy valakinek, elsősorban felelősséggel tartozott érte, befolyását, tudását pedig a közjó érdekében használta. Persze, ha úgy tetszik, ez is érdekek mentén történt, mivel az egyes emberélet biztonságát a közösség szavatolta. Az értékek ennek megfelelöen szerveződtek, és kapott jó vagy rossz előjelet egy esemény vagy történés az adott csoportban. A busmanokat ma még hidegen hagyja, hogy kik versengenek a hatalomért, a túlélésük mástól függ, az együttműködéstől, az őket körbe vevő természeti világ ismeretétől. „A tudás relatív, a spirituális tudás túl lát a mesterséges dimenziókon”" - írja Mihálffy Balázs Mosoly a pokolból című életrajzi regényében, melyből megdöbbentő képet kapunk arról az értékválságról, ami az afrikai törzsek körében végbemegy a rájuk törő modernizáció hatására.

A mindenkori társadalom folyamatosságát, stabilitását az biztosítja, hogy értékeit átörökíti a következő generációkra. Miközben az értékképzés, értékváltozás ugyancsak jelen van, mint az értékőrzés, értékstabilitás jelensége. ${ }^{10}$

Tönnies tipológiája szerint a hagyományos társadalmakat a spontán és természetes társulás a Gemeinschaft (közösség) jellemzi, melyet a közös sorshoz és hagyományokhoz füződő érzelmi közösség tart egyben. Míg a modern polgári fejlödés során létrejött uralkodó társulási forma a Gesellschaft (társadalom), melyet a tagok közös érdekeinek

\footnotetext{
7 Hankiss 2006.

8 Váriné 1987.

9 Mihálffy 2014:150.

10 Váriné 1987.
}

érvényesítése, közös célok elérése hívott életre, alapja a szükségességének racionális belátása. Ezt a megkülönböztetést vezette tovább Weber a célracionális és értékracionális tevékenység és szervezeteik szétválasztásában. A kapitalizmusban az életviszonyok megváltozásával a Gesellschaft típusú szociális társulási-szerveződési módok váltak gyakorivá. ${ }^{11}$

Az értékek tehát absztrakciók, éppúgy eszmei objektivációk, mint ahogyan pl. a pénz, amelyekben emberi ismeretek, vágyak és érzelmek sűrüsödtek egy közmegegyezés eredményeként. Harari jól érzékelteti a bizalom és a képzelet együttes mủködését a pénzen keresztül. Jelenlegi ismereteink szerint az emberen kívül egyetlen állat sem lenne hajlandó arra, hogy egy tápláló élelmiszert elcseréljen egy ehetetlen, használhatatlan színes papírdarabra, és azt gondolja, hogy ezzel jó üzletet csinált. A pénz kizárólag az emberi képzeletnek köszönheti az értékét. Ha megrendül az emberek belé vetett bizalma, akkor ez az érték pillanatok alatt válik semmivé. ${ }^{12}$ Ha ezen elgondolkodunk, akkor a mai értelemben vett gazdagság - amit már nem is színes papírok, hanem számok szimbolizálnak egy virtuális felületen - mint érték, legalábbis kérdéseket vet fel. A napokban elém került egy Adventi Imafüzet, melyben ez a téma így fogalmazódik meg: „Nem az a gazdag, akinek többje van, hanem az, akinek kevesebbre van szüksége".

Mitől lesz, vagy szűnik meg egy érték azzá lenni, ami? Talán nem szolgálja többé a megváltozott társadalmi-kulturális rendben a túlélést. Vagy a cél is megváltozott, már nem a túlélés, aminek érdekében össze kell fogni, hanem a győzelem, vagy a haszonszerzés vagy maga a verseny? Legyőzni másokat, elsőnek lenni, ha csupán egy pillanatra is istenné válni, még ha illúzió is?

Hankiss ezzel kapcsolatban a következőkre jutott: „Lehet, hogy csak akkor érhetjük el, s élhetjük át a szabadságot, ha ki tudunk kapcsolódni a túlélésért és a hatalomért folyó gyilkos küzdelemből". ${ }^{13}$ Önmagunk és az általunk kialakított mesterséges világ foglyaivá váltunk. Geertz ezt úgy fogalmazza meg, hogy: „Az ember a kultúra hálójában vergődo” állat".

Akkor mi is a helyzet a szabadsággal?

Byung-Chul Han a Pszichopolitika címü müvében a XXI. századi fejlett, nyugati társadalmat vizsgálja, konkrétabban a „hagyományos

11 Váriné 1987.

12 Balázs 2017.

13 Hankiss 1977. 
kapitalizmusból" mára kialakult neoliberális kapitalizmust, mely a szabadság és a jólét ígéretével teszi önmaga kizsákmányolójává az egyént. Szekularizált világunkban a tőke lett az új transzcendencia, a kapitalizmus mint új vallás ismét szolgává teszi az embert. „Valóban szabadok akarunk lenni?” Teszi fel a kérdést Han. Nem azért találtuk fel Istent, hogy ne kelljen szabadnak lennünk? Amíg Istennek adósa az ember, nem tud szabadon cselekedni. Ha egészen szabadok lennénk, valóban cselekednünk kellene, ami nagy felelősség, így lett a tőke egy új Isten, aki ismét adósaivá teszi az embert. ${ }^{14}$

„Egy sajátos történelmi korszakban élünk, amelyben a szabadság maga hív életre kényszereket. A 'lehet' szabadsága egyenesen több kényszert teremt, mint amennyit a fegyelmezés 'kell'-je, a parancs és a tilalom kimond. A 'kell'-nek van határa. A 'lehet'-nek viszont nincs. Következésképpen határtalan a kényszer, amely a 'lehet'-ből származik. $\mathrm{Az}$ olyan pszichés betegségek, mint a depresszió vagy a kiégés, a szabadság mély válságának kifejeződései... A teljesítmény-szubjektum, aki szabadnak hiszi magát, valójában szolga... A szabadság voltaképpen a kényszer ellentéte" 15 - állítja Han.

A szabadság kényszerítő erővé vált, a mindenütt jelen lévő, személyi munkatáborunk rabjai és őrei vagyunk. A kapitalizmusban, szemben egy vallással, nincs kegyelem.

Adja magát a kérdés, hogyan lehet ebből kitörni? Egy személyi edző azt tanácsolná, hogy ütemezd jobban a feladataidat, szakíts időt a relaxációra, gyújts egy füstölőt, oldd a stresszt, járj edzőterembe, táplálkozz egészségesen, több vitamin bevitel, meditálj, jógázz, lazulj el egy filmmel, tölts le mind ezekhez egy-egy applikációt, amivel időt és energiát spórolsz, miközben fogyassz még több terméket és élményt esetleg mindezt a barátaiddal a szabadban. Ez sajnos nem lesz elegendő. Talán jó kezdés lenne egyszerűen kevesebbet akarni, kevesebbet birtokolni.

„Csak az az ember lehet szabad, akinek van bátorsága arra, hogy hiteles választások során át maga teremtse meg a maga világát. Aki nem vállalkozik erre, vagy kudarcot vall, azt leigázzák a mindennapi élet rutinjai". ${ }^{16}$

Korok és kultúrák, egyének és csoportok másként konkretizálják és másként is érvényesítik az olyan elvont értékfogalmakat, mint például a szabadság, az egyenlőség stb. Vagyis a kultúraspecifikusság

\footnotetext{
14 Han 2020

15 Han 2020.

16 Hankiss 2005
}

lényegileg módosítja ezeknek az egyetemesnek tünő értékeknek a tartalmát, értelmét és konkrét összefüggéseit ${ }^{17}$ - foglalja össze Váriné.

Jól példázza ezt a cigányasszony és a magyar vizsla esete, amin azóta gondolkodom, mióta az erkélyünkről szemtanúja voltam a történetnek, több éve már. A cigányasszony három gyermekével sétált, egy babakocsi oldalába kapaszkodva ment még két totyogó kisgyermek. Váratlanul egy magyar vizsla termett ott, szertelen ugrándozásba kezdett a gyermekek körül. Az egyik kislány ordítva próbált felkapaszkodni az anyjára ijedtében. A kutya gazdáját kerestem a szememmel, biztos voltam benne, hogy az anya alaposan beolvas neki a gondatlanságáért. A mama azonban ezzel egyáltalán nem foglalkozott, miközben magabiztosan megfogta kislánya vállát, csak annyit mondott: „Mit óbégatsz? Örülj neki, hogy szabad lehet!" Majd körülbelül ebben a pillanatban a kutyus tovaszaladt.

Komoly üzenet ez! Egy másik lény szabadsága akkor is fontos, ha átmenetileg ez zavar vagy megriaszt bennünket. Üzeni, hogy módunkban áll ezzel az érzéssel kezdeni valamit, mert a másik szabadsága is lényeges szempont, nem csak a sajátunk. Ilyen értelemben a szabadság, mint érték elfogadása a társas környezet irányába egy megengedő, elengedő viselkedési attitűd kialakulásának kedvezhet. Örülni a másik szabadságának, némileg más perspektíva a saját szabadságra való kizárólagos érzékenységhez és érzékenyítéshez képest.

Ez a Maslow-piramis alapján az „önmeghaladás" szintje, az egyénen túlmutató érték érvényre juttatása.

Sajátos vonása az értékeknek, hogy érzelmileg hangsúlyosak, szemben a racionális gondolkodással. Továbbá, hogy az életfeltételek és -lehetőségek érzelmi-értelmi feldolgozásának különbözősége következtében függnek az adott társadalom, kultúra domináns ideológiájától. ${ }^{18} \mathrm{Az}$ értékrendszer, ha stabilizálódott, nemcsak a mindennapi tudat világlátásában, hanem a napi tevékenységekben is döntő, motiváló, energetizáló erővel bír, így hat a cselekedetekre és viselkedésre. Ily módon az értékek - ideálisak és reálisak - cél-eszköz viszonyba kerülnek a velük összehangzó szokásokkal és beállítódásokkal. ${ }^{19}$

Kedves példa erre, Eleanor H. Porter: $A z$ élet játéka c. könyvében Pollyanna az árván maradt $\begin{array}{ll}17 & \text { Váriné } 1987 . \\ 18 & \text { Váriné } 1987 . \\ 19 & \text { uo. }\end{array}$ 
kislány, aki édesapja életfilozófiáját próbálja átültetni a hétköznapok gyakorlatába, miszerint: „A boldogság nem egy állapot, hanem egy hozzáállás” - és ezzel élni tanítja egész környezetét.

Kategorizáltam a kurzus során tárgyalt értékeket, egy részük szoros kapcsolatban áll az érzelmekkel, mint a szeretet, boldogság, öröm, barátság, szerelem - univerzálisnak tűnnek ugyan, de a korábbiakból kiderül, hogy az értékfogalmak és ezek jelentései, megélésük és megnyilvánulásaik kultúraés kor-specifikusak.

Akárcsak társaik, melyek a társadalmi-kulturális konstrukciók széles skáláján helyezkednek el, mint az egészség, szabadság, béke, egyenlőség, szépség, tisztaság, hűség, becsület, gazdagság, hatalom. (Csak zárójelben jegyzem meg, hogy a tudás, még inkább a bölcsesség, bizalom, hit, igazság, erő, kreativitás, hála nem szerepelnek ugyan a kurzus listáján, de korábban és még később is lesz róluk szó.)

Elképzeltem egy pillanatra, miként festene a társadalmunk, ha kultúránk hangzatos értékeinek motiváló ereje valóban meghatározná széles tömegek viselkedési szokásait és cselekedeteink ennek megfelelően alakulnának. Az idealisztikus képben nem ismertem fel korunk világát. Ezzel persze nem állítom, hogy ezen értékek nincsenek jelen, hiszen az én generációm valóban békében és szabadságban élhet, legalább is nem háborúban és fogságban.

Bár Byung-Chul Hant olvasva, ebben sem lehetünk olyan biztosak. „A digitális hálózatot kezdetben a korlátlan szabadság médiumaként ünnepelték... A korlátlan szabadság és kommunikáció most totális ellenőrzésbe és felügyeletbe csap át... A társadalmi média digitális panoptikumra emlékeztet, amely a társadalmat felügyeli és kíméletlenül kizsákmányolja”. ${ }^{20}$

Ezen az elven, hogy valami pont az ellenkezője is lehet, mint aminek láttatja magát, az értékek mellé összegyűjtöttem az ellentétpárjukat. Arra voltam kíváncsi, hogy korunk és kultúránk értékeinek ellentétei mennyire és milyen elöjellel vannak jelen életünkben?

Az érzelem értékek ellentétjei: utálat, boldogtalanság, bánat, gyűlölet, ellenségesség/elidegenedés.

A társadalmi-kulturális konstrukciók ellentétei: betegség, rabság, háború/harc, egyenlőtlenség, rútság, piszkosság, hűtlenség, becstelenség, szegénység, alávetettség. Az értékeink csokorba gyüjtött ellentétei által megidézett atmoszféra nem ismeretlen számunkra. Megdöbbentő felfedezés, persze nem tudományos megállapítás, hogy kinyilatkoztatott

20 Han 2020. értékeink ellenkezője éppúgy jellemző jelenlegi világunkra, amennyiben a híradásokat és a világjárványt veszem alapul. Byung-Chul Han egy másik műve: A kiégés társadalma rajzolódik ki a felsorolásból.

Esett szó arról, hogy az értékek absztrakciók. Mi sem érzékelteti ezt jobban, mint annak idején egészségügyi tanulmányaim során az első lényeges fogalom, a WHO egészség-meghatározása, ami így hangzik: „Az egészség nem a betegség hiánya”. Azóta sokszor eljátszom az ellentétek ilyenforma összeillesztésével, mert érdekes távlatokat nyit. Kétségtelenül igaz, hogy például egy szemproblémával élő ember szemüveggel nem gyógyul meg ugyan, de tökéletesen funkcionál. Tehát ha bizonyos feltételek teljesülnek, habár fennáll a betegség ténye, mégis egészséges életet lehet élni. A képletet alkalmazva: az emberélet nem a halál hiánya, a gazdagság nem a szegénység hiánya, a béke nem a viszály hiánya, a boldogság nem a boldogtalanság hiánya, a szabadság nem a rabság hiánya, az öröm nem a szomorúság hiánya, a szépség nem a rútság hiánya, a tisztaság nem a piszok hiánya és így tovább. Érdekes kísérlet az értelmezés tekintetében tovább játszani ezzel és megfordítani: a betegség nem az egészség hiánya, a halál nem az élet hiánya, a szomorúság nem az öröm hiánya, stb. Elsőre mindez vagy értelmetlennek, vagy filozófiai magaslatnak tűnik, pedig vannak kultúrák, melyekben léteznek kifejezések a szomorúság és öröm vegyületére, ami arra utal, hogy érzéseikben együttesen van jelen.

Meghatározó értékeink mibenlétén tovább elmélkedve arra gondoltam, vessünk egy pillantást a mózesi Tízparancsolatban megjelenő értékekre, valamint a Babilon Nyulai Kerékpáros Egyház hitrendszerében „degrowth”21 szemléletű értékekre, ami egy modern alulról jövő kezdeményezés, s mint ilyen, korunk valóságának egy szelete. Majd ezt követően vizsgáljuk meg a tudományosan meghatározott emberi szükségleteket és értékeket, a Maslow-piramis segítségével, végül említés szintjén Schwartz értékelméletén keresztül, az elemzés teljességének igénye nélkül. Arra voltam kíváncsi, van-e közös metszete a bennük megfogalmazódó értékeknek, és ha igen, melyek azok.

Az első kőtábla a Teremtővel kapcsolatos kötelességeket fogalmazza meg, a második a kötelességeket embertársaink felé:

1. A Teremtő uralmának elismerése (a teremtettség elismerése)

21 https://www.degrowth.info/en/nyilt-level/ 
2. A teremtés egysége és szellemisége

3. Hamis és fölösleges eskü ellen

4. A szombat, ünnepnap szentsége

5. A szülők tisztelete (a tradíciók tisztelete)

6. Az emberi élet szentsége

7. A házasság szentsége

8. A vagyon szentsége

9. A hamis tanúskodás ellen

10. A mohó kívánság ellen.22

A kőtáblák egyike tehát az Isten-ember szövetségét, a másik az emberek egymás közötti szövetségét szimbolizálja. Ezt Jézus két parancsolatban foglalta össze:

A Teremtő szeretete, mely szerintem a teremtett világ szeretetén és tiszteletén keresztül valósulhat meg. Lényege, hogy Minden Egy.

A felebaráti szeretet, azaz „Szeresd felebarátodat, úgy, mint magadat." ${ }^{23}$

A felebaráti szeretet a keresztény élet és erkölcs egyik alaptanítása. Életünk össze van kötve más emberek életével, akár csak a természeti világ minden elemével. A Biblia tanítása alapján „emberre”” igazán csak emberek közösségében lehetünk. Mindig a másokkal levő kapcsolatban éljük meg a társadalmi és szociális életünk lényeges részét, de ez csakis a fizikai és biológiai világ rendszerén belül valósulhat meg. Eszerint az egyes emberen keresztül árad a Teremtésből jövő szeretet - tovább minden ember, sőt minden teremtett lény, a komplex teremtett valóság felé. Ismét Hankiss: „Hiszek a szeretet fontosságában, ha ez a szó azt jelenti, hogy együtt vagyunk egy végtelen, üres, sötét univerzumban; hogy próbáljuk enyhíteni mások szenvedését, óvjuk egymás életét; segítünk egymásnak abban, hogy tisztességgel megálljuk a helyünket, hogy életünk kiteljesedjék, hogy el tudjuk fogadni életünk törékenységét és mulandóságát; segítünk egymásnak szembenézni a mulandósággal, minden dolgok hiábavalóságának fenyegető kételyével". ${ }^{24}$

Egyházi esküvőm a Babilon Nyulai Kerékpáros Egyház zászlaja, helyesebben biciklikerék abroncsa alatt köttetett. Azért tartom fontosnak itt ismertetni a hitrendszerét, mert a modern kor problémáira válaszul egy átgondolt, környezettudatos és fenntartható értékrendszert közvetít. A „degrowth” szemlélet szembe megy azzal, hogy „a több szükségszerủen jobb”, vallja, hogy a fejlődés minőségi és nem feltétlenül mennyiségi gyarapodással érhető

22 https://mazsihisz.hu/a-zsidosagrol/judaizmus/ torvenyek/a-tizparancsolat

23 Gal 5.14.

24 Hankiss 2006. el. A nemnövekedés egy politikai, gazdasági és társadalmi mozgalom, melynek alapját környezetvédelmi, fogyasztásellenes és antikapitalista eszmék alkotják. Mivel a kapitalista rendszerben környezetvédelmi aggályok és társadalmi egyenlőtlenségek gyökereznek, a növekedésellenzők célja, hogy a nemfogyasztás révén maximalizálja a boldogságot és a jólétet, még inkább a jóllétet munkamegosztással, kevesebb fogyasztással, művészetnek, zenének, családnak, kultúrának és közösségnek szentelt idővel. ${ }^{25}$

„Ahelyett, hogy folyton-folyvást lázasan csinálunk valamit, hagyni kellene, hogy a dolgok történjenek a világgal és velünk. Be kellene engednünk az életünkbe a véletlent és a szabadságot, $s$ hagyni a világot, hogy teremtse önmagát. Meg kellene tanulnunk újra egyszerűen csak lenni, létezni. Tanulnunk kellene a játszó gyerek mély áhítatából és békességéből." ${ }^{26}$

A Babilon Nyulai Kerékpáros Egyház egy olyan „szabadegyház”, ami a biciklivel közlekedés „általi szabadulásra" és a HÉT elvének tiszteletére épül. „A mi egyházunknak nincs hatalma, nincs vagyona és nem is lesz soha. Létünk a szabad döntésre épül, arra a velünk született ősi jogra, hogy szabadok vagyunk. Életünkkel és munkánkkal új világot építünk... azokat hívjuk magunk közé, aki érzik magukban a jóság mélyről jövő erejét, az építő törekvést arra, hogy a saját életükben teljesedjenek ki azáltal, hogy másokat és a világot is jobbá teszik... befogadunk mindenkit, aki elfogadja a szabadság tiszteletét, a tekerés diadalát és a HÉT-re törekvés mindennapi gyakorlatát." ${ }^{\prime 7}$

A jobb - nem feltétlenül a sikeresebb, a gazdagabb, a szabadság - itt abban az aspektusban értelmezendő, hogy felszabadítjuk magunkat a hét alapelvre törekvés, valamint a biciklizéssel - ami talán a legkevésbé kártékony közlekedési forma a sétálás, futás után - a mozgás által.

\section{„A HÉT}

Szabadság - mindennek az alapja.

Béke - a létezés nyugalma.

Szeretet - a boldogság forrása.

Nagylelkűség - a lélek tápláléka.

Tudatosság - a fejlődés gondolata.

Hasznosság - az alkotás öröme.

Mértékletesség - a gyönyör útja." ${ }^{28}$

Amint az jól érzékelhető ez a rendszer egy közösségi gondolkodásra, fenntartható fejlődésre való

25 http://nemnovekedes.net/

26 Hankiss 2005.

27 https://www.facebook.com/babilonnyulai

28 https://www.facebook.com/babilonnyulai 
törekvést feltételez, visszakacsintás a Gemeinschaftba, a természeti környezet iránt érzett felelősséggel kiegészítve.

Az értékrendszerek és maguk az egyes értékek akár ösztönző példaként (Babilon Nyulai), akár korlátozó tilalomként (Tíz parancsolat) hatnak - részei az egyéni és csoportos viselkedés társadalmi kontrolljának. Ahogy már volt róla szó, az értékrendszerek sajátos, kultúrafüggő objektivációs rendszerek, amelyek kialakulásukkal és megszilárdulásukkal párhuzamosan további szabályrendszereket építenek ki. Ily módon jóformán az élet minden területére kisugároznak. Az erkölcsi értékek például, nem függetlenül egyéb anyagi és szellemi értékektől, kisugároznak a gyakorlati erkölcsre, az erkölcsi szokásokra, továbbá a politikai és jogi elvekre és a joggyakorlatra. Az a fajta szimbolikus és részben tudatos, de mindenképp tudatosítható értékelő viszony, amely az emberi értékekhez vezet, döntően a társadalmi léthez, a nyelvhez és a tudathoz, a valóság szimbolikus ábrázolásának a képességéhez kötött. ${ }^{29}$

A Maslow-piramis az egyén társadalommal való viszonyát az egyén szemszögéből vizsgálja.

A motivációs piramis szintjei mellé próbáltam rendelni a szintnek megfelelő értékeket:

1. Fiziológiai szükségletek (levegő, fény, élelem) - emberélet.

2. Biztonsági szükségletek - hajlék, egészség, testi, anyagi biztonság.

3. Szeretet, valahová tartozás szükséglete - család, barátok, közösség, barátság, bizalom, elfogadás és szeretet. A másik ember iránti szükségletről van szó, nem egyszerűen biológiai társra, közös referenciapontként a valóságértelmezéshez. Minden embernek szüksége van elfogadásra, méltánylásra, elismerésre, nem csak segítségre a fizikai fennmaradásban. ${ }^{30}$

4. Elismerés szükséglete - magunkra irányuló: önértékelés, önbecsülés, méltóság, függetlenség, másoktól felénk irányuló: státusz, presztízs, elismerés, népszerűség, hatalom.

5. Kognitív szükségletek - az ismeretlen felfedezése, az összefüggések megértése, a tudás.

6. Esztétikai szükségletek - szépség, a rend, a tisztaság.

7. Önmegvalósítás útján olyan egyénné válhatunk, aki képességeit maximálisan

29 Váriné 1987.

30 uo. kihasználja és a rendelkezésére álló lehetőségekkel maradéktalanul él.

Az önkifejezés-önmegvalósítás mindig társas mezőben, a hasonulás és elkülönülés, a konformizálódás és az önállósulás rendkívül összetett folyamatai közepette érvényesül, hiszen az értékek a társadalmi társas cselekvéssel valósulnak meg. ${ }^{31}$ Tovább gondolva Váriné megállapítását, nemcsak a társas környezetben, de szükségképpen a természeti környezetben, gyakran egyikmásik vagy mindkettővel való visszaéléssel, kizsákmányolásával valósul meg az ember önmegvalósulása. De vajon mi motiválja erre az embert?

Han szerint az, hogy képtelenek vagyunk ellenállni az illúzióknak, hogy „elérhetünk bármit”, hogy „sikeresek lehetünk, „valakik” lehetünk, hogy „meggazdagodhatunk”. „Az emberek saját magukból üzletet csináló vállalkozókká váltak" - és nem állnak meg önmaguk kizsákmányolásánál. „A digitális kor rabszolgái vagyunk", az egyéni törekvés, a növekedés és a motiváció szlogenjei több mint elegendőnek bizonyultak, hogy a „kiégésig hajtsuk önmagunkat”. Társadalmunk túlságosan individualizált, a teljesítmény maximalizálásához szükséges erőforrásokért folytatott küzdelemben valójában önmagunk válunk a legnagyobb ellenségünkké. ${ }^{32}$

8. Önmeghaladás - Ezzel a szinttel Maslow utólag egészítette ki a modelljét, így nyilatkozik erről: „A transzcendencia az emberi tudat legmagasabb, legátfogóbb vagy holisztikus szintjeire utal, viselkedésként és célként, nem pedig eszközként kapcsolódva önmagához, másokhoz, általában az emberekhez, más fajokhoz, a természethez és a kozmoszhoz." 33

A modellnek, mint a legtöbb társadalomtudományos elméletnek megvannak a maga hiányosságai, például, hogy az angolszász kultúra sajátosságai és értékei alapján készült, így korlátozottan vagy egyáltalán nem alkalmazható eltérő kultúrájú társadalmakra.

\footnotetext{
31 uo.

32 Fiala 2017.

33 Szakács 1985.
} 
Ez a modell sem számol az egyének közötti különbségekkel, illetve a különböző életszakaszok eltérő preferenciáival sem.

A szinteket nem tekinthetjük egymásra épülő szükségleteknek, valójában nem is egy piramis ugyanis, időnként alsóbb szintű szükségletek kielégületlenül maradnak, mégis képesek vagyunk energiáinkat mozgósítani egy magasabb szintű célért. ${ }^{34}$ Mint ahogy majd látni fogjuk a hajléktalan alkotók esetében.

Edith Eva Eger pszichológus, holokauszt-túlélő $A z$ ajándék című könyvében például arról ír, hogy miként tanult meg egy haláltáborban élni azáltal, hogy kinyitotta tudata börtönét. Összefoglalva így fogalmazza meg: „A szabadság alapja az erő, hogy dönteni tudunk... a szabadság alapvetően a döntésről szól... nem az számít a leginkább, hogy mi történik, hanem hogy mit kezdünk a tapasztalatainkkal”. ${ }^{35} A$ döntés c. könyve arra tanít, hogy „a körülményektől függetlenül dönthetünk úgy, hogy az örömöt és a szabadságot választjuk...”36

Ezek a gondolatok $A z$ élet játéka címü könyv üzenetével paralellek, mintha azt mondaná: a szabadság sem egy állapot, hanem egy hozzáállás, egy paradigma. Arra utalnak a sorai, hogy némiképp függetlenül a megtapasztalható fizikai valóságtól, a tudatunk segítségével megteremthetjük a szabadságunkat. Ez az a mechanizmus amiről Harari is beszél. Miszerint az ember nem csak a fizikaibiológiai valóságban él, képes létrehozni egy képzelt valóságot is. ${ }^{37}$ Hankiss még átfogóbban így látja: „A gondolatok univerzumában is, és - ha ez valami más - a fizikai törvények univerzumában is lehet rab vagy szabad az ember. Pillanatnyilag még nem tudjuk, hogy mennyire vagyunk rabok, $s$ mennyire vagyunk szabadok. A világmindenségnek még csak elenyésző töredékét ismerjük" ${ }^{38}$

A Schwartz-féle tíz alapérték és jellemzői, felsorolás szintjén a következők:

1. Altruizmus: becsületesség, barátság, őszinteség, segítőkészség, megbocsátás

2. Univerzalizmus: tolerancia, igazságosság, szolidaritás, kölcsönösség, béke, környezetvédelem

3. Autonómia: szabadság, függetlenség, kreativitás, önbecsülés

34 Szakács 1985.

35 Eger 2020.

36 Eger 2020.

37 Balázs 2017.

38 Hankiss 2005.
4. Biztonság: anyagi, fizikai, személyes, biztonság, a harmónia, egészség, rend

5. Hedonizmus: öröm, élvezetek

6. Teljesítmény: siker, érvényesülés, befolyás

7. Tradíció: kollektív tudás, hit

8. Kockázatvállalás: újdonság- és kihíváskeresés

9. Konformitás: önfegyelem, engedelmesség, tisztelet, lojalitás

10. Hatalom: státusz és presztízs, gazdagság. ${ }^{39}$

A motivációk alapja végső soron az ember biológiai és társadalmi szükségleteinek láncolata, és az ezekre jól-rosszul ráépült érdekek sora. Lehetnek az embereknek olyan értékeik is, amelyek önnön érdekeikkel is szemben állnak. ${ }^{40}$

Itt egy nagyon érdekes és lényeges összefüggésre hívja fel a figyelmünket Váriné. Tovább vinném a gondolatot, mégpedig úgy, hogy megfordítom. Lehetnek az embereknek olyan érdekeik, melyek önnön értékeikkel is szemben állnak. Ez az egyénre önmagára, és/vagy társas környezetére, de akár a természeti valóságra nézve lehet destruktív, és konstruktív is. Ez szerintem egy nagyon összetett gondolat, sokat gondolkodtam azon, miként lehetne ezt valahogy szemléltetni.

Sánta Ferenc $A z$ ötödik pecsét címủ regényének az alapvető kérdése ez. A Gyurica által feltett kérdés, Gyugyu vagy Tomoceuszkakatiti szerepét vennénk-e fel? A kérdés mélyen filozófiai, több annál, hogy az életet vagy a halált választanánk-e. Mindenki Gyugyut választja, csak Gyurica Tomoceuszkakatitit. Úgy tűnik, hogy elárulja a többieket, saját magát, és a lelkiismeretét is. És itt van elásva a tömör zsenialitás. Nem saját magáért cselekszik így, hanem azokért a gyerekekért, akiket a házában bújtat a nyilasok elől. Így tehát ez a cselekedete nem tekinthető öncélúnak, hanem inkább saját maga, lelki békessége, üdve feláldozásaként a gyermekekért. ${ }^{41}$

Az értékek rejtőzködnek, közvetlenül nem hozzáférhetőek, létükre igazán akkor döbbenünk rá, ha eltűnnek. Az értékek keletkezése és léte a társak iránti szükséglettel áll szoros kapcsolatban. A vallások értékei is ezt bizonyítják. A modern társadalmakban a hagyományos „természetes” közösségek felbomlásával, az atomizálódással és elidegenedéssel, újfajta értékorientációk és értékzavarok keletkeznek.

39 Prazsák 2015

40 Váriné 1987.

41 https://ervelokritikus.blog.hu/2015/04/29/ miert_zsenialis_az_otodik_pecset 
A tudomány, mint igaz ismeretek felhalmozója, valójában érték-érdek mechanizmusok mentén befolyásolt, bár „igaznak” és „objektívnek” állítja be magát. ${ }^{42}$

A csoportméret növekedésével a bizalom és az együttműködés szintje visszaesik. Ennek ellensúlyozására alakultak ki az állam szociális intézményei. A modern társadalmakban a piac és a nemzetközi munkamegosztás hatására a proszociális értékek kettős változáson mennek keresztül. Egyrészt, az idegenekre is kiterjed a bizalom és az együttműködési készség, ugyanakkor a piac és a pénz erodálja a szociális kapcsolatokat. ${ }^{43} \mathrm{Ez}$ ismét az érték-érdek kettősség, ami egyszerre van jelen világunkban, izgalmas lenne ennek a jelenségnek az interdiszciplináris kutatása.

Szociálpszichológiai szempontból az értékek léte az emberi tevékenység szándékos, akaratlagos és tudatosítható voltával, valamint a közösségi létezéssel és vonatkozási rendszerével függ össze. ${ }^{44}$ Ezek az egyén érvényesülési stratégiáiban érhetők tetten, és megjelennek a tudományos értékmodellekben is. Ugyanakkor az ősi vallások értéklistáján nem szerepelnek pl. a gazdagság, sikeresség, hatalom manifesztumai, ha mégis, akkor negatív előjellel. Meg kell említeni, hogy a modern populista vallási csoportok már annál gyakrabban operálnak vele.

A következőkben áttekintem, milyen értékekkel foglalkoznak napjaink irodalmi alkotásai, a reklámok, valamint, újságcikkek és publikációk tartalomelemzésével kirándulást teszek társadalmunk különböző rétegei között, hogy megtudjuk, milyen értékeket jelenítenek meg, milyen értékeket adnakvesznek, milyen értékek fontosak számukra, számunkra valójában. Végül röviden bemutatom saját eddigi multikulturális családok körében végzett kutatásom gyermekneveléssel kapcsolatos értékelgondolásait.

Elsőként a Könyvhét 2020/4. számának könyvajánlataiban szereplő könyv címekben és tartalmakban megjelenő értékek után kutattam. Idő és hely hiányában, zanzásítva a következők voltak: "Öröm”, „Az empátia árnyoldalai”, a „Giccs és müvészet” című könyv az érték csalárdságáról, „A szenvedélytől a harmóniáig”, „A szeretet útján”, „Nem első, hanem jó akarok lenni”, „Az örökkévalóság hangjai”, „Tanulj meg meditálni”. A „Madárember” c. könyv: boldogságról és szabadságról, a „Trianon

\footnotetext{
42 Váriné 1987.

43 Marosán 2007.

44 Váriné 1987.
}

Fiai”: szerelemről szólnak. „Büszkeség és balítélet”. A „Vihar után”-ban a tökéletes boldogságot keresik. „Megfagyott idő”: küszködésről, örömről, bánatról, boldogságról szól. „Az apa”: a hírnévről, verhetetlenségről, sorsfordításról, szeretetről. „Kiotó”: mindent felülíró szerelemről szól. Születtek írások a szépségversenyekről, melyben lázadnak a szépnek kikiáltott tömegízlés ellen. „A boldog hülye és az okos depressziósból”: „Tegnap okos voltam és meg akartam változtatni a világot. Ma bölcs vagyok így megváltoztatom magam”. „Az Anyák és kamionsoförök" című novellakötet az érték utáni vágyakozásról szól, megmutatja szereplői kudarcait, családok széthullását, küzdelmeit, szól a szexről, a kényszerről. A „Hej, Sionról fúj a szél”-ben a zsoltárok békességet árasztanak. „Isaac Newton” az öntörvényű, gátlástalan zseni. Szólnak még könyvek uralkodókról, hírességekről, „Mikrofon bálványokról”, szóval a hatalom és a siker mibenlétéről. „Aranyemberek” - interjúk Magyarország leggazdagabb embereivel. Szerelem, szerelem és szerelem, könyvek sokaságának tartalma különböző történelmi korban és időben, szeretetről versek, idézetgyüjtemények, elmélkedések. A gyerekkönyvekben a család a barátság fontossága hangsúlyozódik, a mesékben bölcseletek vannak, a „Játékosan a Bibliáról” címü könyvben az engedelmesség, a barátság, az egészség és hála értékei jelenítődnek meg. A karácsonyi témájú könyvek a nyitottságra és együttérzésre, a mindennapi csodákra érzékenyítenek. Miközben a gyerekek világát azért mégis egy akcióhős-univerzum uralja. Könyvek sokasága ad útmutatót a boldogsághoz, sikerhez, gazdagsághoz. Úgy tủnik, egyértelmű válaszokat keresünk egy többértelmű világban, a boldogság számos megközelítése létezik a meséktől a vallásokon át az életvezetési praktikákig.

A boldogsághoz való viszony kultúra kérdése is. Az amerikai társadalomban boldognak és sikeresnek illik lenni, és a tömegmédia globális térnyerésével a Facebookon is bárhol a világban. A boldogság és a sikerkultusz manapság világdivat. Meg kell szerezni, meg kell venni, bár közhelyé vált igazság, hogy azt nem lehet, mármint megvenni a boldogságot, akkor legalább az illúzióját. Máris segítségünkre sietnek a reklámok és a piac, irányt mutatnak és receptet adnak vagy ekvivalenssé varázsolják nekünk a boldogságot egy örömteli élménnyel, egy illatos habos fürdővel.

A Douglas reklám-magazin 2020. tél - kozmetikai termékek, parfümök című kiadványban megjelenő értékek listája a következő: szépség, csábítás, luxus, szépség, csillogás, varázslatba burkolódzó 
megjelenés, fiatalság, magabiztosság, erő, szenvedély, minőség, tökéletesség, praktikusság, gazdagság, harmonikus megjelenés, egészséges bőr. Már Nietzsche is megmondta, hogy "Isten halála az egészséget istennővé emeli”. A szépséggel sincs ez másként.

Íme, egy sokat mondó reklámszöveg mely értékek sokaságát sűríti magába, a termékeladás céljából.

„A boldogság ajándéka - oszd meg másokkal is az örömöd:

Az idei ünnepek során gondolj hálával szeretteidre, és ajándékozd meg őket egy csodaszép ajándékszettel! Minden Rituals ajándékszett magában rejti a hála, a szeretet és az odafigyelés ajándékát".

A magazinok Karácsony előtti hirdetései megnyugtatnak, hogy együtt töltött minőségi idő hiányában, egy drága, vagy legalább szép karóra, boldogság helyett az elégedettség érzése is megteszi. Az embereket az érdekli, manapság mit tudnak megvenni és nem az, mit tudnak megtenni az egészségükért, a boldogságukért, önmagukért.

Van még egy érték, amit ugyan nem találtam sem a Schwartz-féle értékrendszerben, sem a Maslow-szükségletek alapján nem tűnik elengedhetetlennek, a vallásokban sem jelenik meg, a könyvek témáiban és az újságcikkek hasábjairól sem köszön vissza, legalábbis explicit módon. Talán csak a Babilon Nyulai Kerékpáros Egyházban van rá utalás - mint elkerülendő motivációra. Azonban az utóbbi hónapok gyüjtései és tudatos megfigyelései során unos-untalan belebotlottam, mint döntéseinket, választásainkat meghatározó elérendő célként előttünk lebegő vágyott és megérdemelt értékre. A reklámok szövegei nem engedik, hogy megfelejtkezzünk e szempont fontosságáról, mindeközben olyan természetessé vált az erre vonatkozó igényünk, hogy már fel sem tünik a nem magátólérthetősége.

Egyszer csak szembe jött velem egy gigantikus méretű óriásplakát a következő felirattal: „Kényelmes Karácsonyt!” A kényelem az, ami nagyon is meghatározza a hétköznapokban a döntéseinket, választásainkat és cselekedeteinket. A középosztálytól felfelé, otthonaink egyre kényelmesebbek, a kanapék egyre nagyobbak, az ágyak matracai egyre puhábbak, a ciponnk és a ruházatunk nem csak praktikus, vagy szép, kényelmes kell, hogy legyen - természetesen. A bicikliket, rollereket pillanatok alatt lecserélte azok elektromos változata, mert sokkal kényelmesebb. A kapu, a tv, a világítás távirányítóval múködik, nehogy meg kelljen tenni pár métert az aktiválásukhoz, hiszen mindez kényelmesebb a kocsiban ülve, vagy a kanapén elterülve. A technikai vívmányaink jelentős része, a mosó- és mosogatógép, a személyszállító lift és még sorolhatnám. A szeletelt kenyérre ez van írva: „finom, friss, szeletelt - az ön kényelméért”. Interneten vásárolunk, megrendeljük, házhoz szállítatjuk, mert úgy még cipekedni sem kell. Persze az idődimenziót segítségül hívva, mindezt meg tudjuk ideologizálni, hiszen időt spórolunk vele - elvileg. Azonban életünk minden területén a kényelemre törekszünk, sokszor a kapcsolataink kialakításában, fenntartásában is. Itt már nehezebben értelmezhető az időoptimalizálás, mint magyarázat.

„A modern emberiség óriási hasznot húzott a tudományok diadalmas elörehaladásából. A modern világ kényelme a tudomány eredményeire épül. Mindannyian haszonélvezői vagyunk". Hankiss ${ }^{45}$ szerint (Han meglátásait továbbgondolva) talán azért nem áll érdekünkben változtatni az önkizsákmányolásunkon, mert ez a rabszolgaság kényelmes rabszolgaság, s mint olyan úgy néz ki vonzóbb, mint egy kényelmetlen szabadság. Mint a Mátrix c. film központi döntés-dilemmája: a kellemes illúzió szemben a kellemetlen valósággal. Ez a jelenség túlmutat a konformizmuson, leginkább komfortizmusnak nevezném.

Nem csalódtam Hankissban, ebben a témában is volt mit mondania: „Ma már tudjuk, hogy törekvéseink az egyre nagyobb biztonságra és az egyre nagyobb kényelemre a pusztítás és a pusztulás veszélyét is magában rejtik. Ma már tudjuk, hogy megvan a hatalmunk rá, s talán még a hajlamunk $s$ felelőtlenségünk is, hogy megsemmisítsük önmagunkat". ${ }^{46}$

Megvásárolva próbáljuk elnyerni a szépséget, boldogságot, szabadságot és paradox módon folyamatosan dolgozunk érte, amit pedig megveszünk, az tárgyakon, élményeken keresztül az illúzió.

Pedig a magyar származású ausztrál professzor, Forgács József egy kutatásában kimutatta, hogy a szomorúságnak is számtalan előnye van. Ilyenkor jobb a memóriánk, pontosabb az ítélőképességünk, csökken a hiszékenységünk, pontosabb az érvrendszerünk, motiváltabbak vagyunk, szociálisan érzékenyebbek és kevésbé önzők vagyunk. Ezt szintén a könyvhét ajánlataiból tudtam meg.

$\mathrm{Az}$ emberi boldogságigény, az egyéni boldogság társadalmilag elismert és legitim szükségletté a reneszánsz és az újkor hajnalán vált, s lett értékké

45 Hankiss 2004.

46 Hankiss 2004. 
a polgári ideológiában és etikában. Ugyanakkor a személyiség lényegéhez tartozó magasabb értékek tudományos, politikai, ideológiai, művészi, erkölcsi értékek - érvényesítése az önérvényesítés szükségleteként is müködik. Visszatérve a szükségletek és az értékek közötti összhang kérdésére: a társadalom anomikus állapotai vagy társadalmak és mozgalmak hanyatló stádiumai jól példázzák az összhang megbomlását. Teljes összhangról voltaképpen sohasem beszélhetünk, minthogy az emberi szükségletek fejlődése, az érdekek, valamint az értékek változása sohasem teljesen párhuzamos láncolatok. A közöttük támadó feszültségek viszont nagyon is közrejátszanak az értékek újabb és újabb - minden generáció által egyszerüen létérdekből spontánul is végrehajtott - „minősítésében”, szelektálásában és elfogadásában. ${ }^{47}$

Az emberi létezés teli van kisebb-nagyobb jelentőségü döntésekkel, ezekről a döntésekről szól minden. A könyvek többsége alapkérdéseket boncolgat: élet, halál, szerelem. Azonban mennyire mást jelentenek ezek a fogalmak, értékek a fejlett nyugat alsó, közép és felső osztálya számára. Mennyire mást a budapesti hajléktalannak, a borsodi cigánysoron a mélyszegénységben, kilátástalanságban élőnek, és ismét csak mást Afrika, áram- és vízellátás nélküli kis településein.

A Fedél Nélkül hajléktalan újságokat is átlapoztam értékek után kutatva. Éles a kontraszt a csillogó reklámújságokkal, címszavakban: hideg, sírás, éhség, fagy, sötét, félelem, egyedüllét.

A 2020. szeptember 10. /XXVIII. évf., 681./ számban Rubik Ernő azt mondja: „Szerintem a legfontosabb, hogy megőrizzük szívünkben a játékosságot és a kíváncsiságot”. Az utcán élő emberek novelláiban, verseiben a következő értékek és ellenpólusaik szerepelnek: halál, szerelem, az igazság sokszor, aztán a jóság, a halál mint pótcselekvés, méltóság, nyugalom, okosság, szelídség, boldogság, szeretet, mámor, hajlék. A 2020. október 22. / XXVIII. évf. 684./ számban a „Fedél Népkül”-ben (a cím is utalás egy szabadság-szükségletre, mivel az 5 éve megszűnt, Népszabadság szerzői gardája azóta hagyományosan olykor-olykor az utcalap hasábjain publikál): humánum, hősiesség, hűség, mámor, erő, empátia, bátorság. Ebben a számban Nádasdy Ádám szerint a tudás, a tudás-átadás, a zene képvisel értéket. A hajléktalan költők életről, bátorságról, szépségről, szép halálról, boldogságról, kacagásról, nevetésről és három esetben szerelemről írnak. A 2020. november 05. /XXVIII. évf., 685./ számból

47 Váriné 1987. megtudjuk, hogy Vecsei H. Miklós színész számára a szeretet és őszinteség fogalmak köré rendeződnek az értékek. A versekben, írásokban felbukkanó értékfogalmak a következők: érdeklődő, segítőkész, kommunikatív, rend, béke, szép, becsület, igazság kétszer, öröm, gyöngye, szerelem, kegyelem, szeretet, bátorító jó szó. A pénz egy esetben szerepelt a versekben, kincs, gyönyörü lányok, kincs, hűség, rend, szép arcod, gyengéd érintés, öröm, élet, születés, hűség, büszkeség, létezés, bátorság, humor, hit, szerelem, idő, biztonság, igazság, egyenlőség.

A 2020. november 19. /XXVIII. évf., 686./ számból az öröm, szerelem, boldogság, szép, hüség, becsület, őszinteség, mosoly, lét, ölelés-szeretet köszönnek vissza. Müller Péter Sziámival készült interjúban a szeretet, barátság, bizalom fontossága jelenik meg. 2020. december 03. /XXVIII. évf., 687.I szám értéktartalma címszavakban: segítőkészség, emberélet, barátság, öröm, ölelés, bölcsesség, család, hit, csók, szerető, szerelem, segítség, fedél. Végül a 2020.december 31. /XXVIII. évf., 689./ számban Kormos Anett forgatókönyv író, humorista gondolatai közt a következőket találjuk: „Humor, mint a túlélés eszköze", élet, család, kapcsolatok.

A fedél nélkül élő emberek írásaiban leggyakrabban megjelenő érték a szeretet, szerelem, egyszer szerepel a pénz, gazdagság. A hatalom például egyszer sem jelenik meg. A hajlék nélkül élő emberek fiziológiai szükségleteinek kielégítése éppúgy bizonytalan, mint a biztonság, vagy a valakihez tartozás. Mégis életükből legtöbben nem az alapvető kényelmet, vagy anyagi javakat hiányolják, miközben rengeteget nélkülöznek ezen a téren, hanem a szeretet-kapcsolatokat, a kötődést. Bámulatosan kreatív megoldásokat találnak az alapvető szükségleteik kielégítésére és a bizonytalanság elviselésére, igényeiket a lehetőségeikhez szabva. Sokszor „Gyugyu” működésbe kapcsolva, önbecsülésüktől megfosztva, egyfajta méltósággal tekintenek az őket ignoráló környezetre. Nem egyszer nagyon építő beszélgetésekben van részem egy-egy utcalap terjesztőjével. Irodalmi alkotásaik pedig gyakran zseniálisak, érzékenyek és összetettek, nem hiányzik belőlük a humor, az önirónia és a társadalomkritika sem. Érdemes lenne írásaiknak egy kutatást szentelni. Helyzetüknél fogva sajátos, eredeti nézőpontból fogalmaznak, alkotásaik sürítve tartalmaznak valóság olvasatokat. „És néha a mindenség mutatja, Ami sokkal inkább túlmutat rajta” Viola Krisztián, Megnyílik című verséből.

$\mathrm{Az}$ értékeknek is van énvédő szerepük, hasonlatosan az attitűdökhöz. Betöltenek továbbá önkifejező, önépítő és önmegvalósító funkciót, és 
rendelkeznek ismeretfunkcióval is, hiszen rendezik a társadalmi jelenségek világát, és a személy társadalmi orientációját szolgálják. ${ }^{48}$ Valamennyi fennálló intézményén belül vannak rejtettebb vagy nyíltabb, egymást támogató vagy egymással ellentmondásban levo „értékközvetíto”” csatornák, ilyenek a szokások, szerepek, sztereotípiák. ${ }^{49}$

A Mandinerben rábukkantam egy számomra megdöbbentő interjúra egy jogász-íróval. Kötter Tamás következő sorai jól példázzák számunkra a társadalmi osztályok között feszülő értékbeli különbözőségeket:

„- Melyik lenne, ha csak egyiket választhatná: hires ügyvéd vagy hires iró?

A Porschémat választanám. Már mondtam máshol is. Ez nem változik, sajnálom.(...)

A magyar társadalom lélegzete: az M7-es autópályán sorjázó dugók a Balaton felé. Bocs, de ez van.

Mindig a törzset kell nézni, aki viszi előre az országot, nem azt, hogy a világ végén iskolázatlan félalkoholisták éppen mit csinálnak. Senkit nem érdekel, mert semmilyen hatásuk nincs a jelenre, nemhogy a változásokra.(...)

Hiányzik a szembenézés azzal, hogy milyen világban élünk, kik vagyunk mi, milyen vágyaink vannak, és ezekből mi teljesül. Attól félnek az írók, hogy nevetségessé válnak, ha a vágyaikról írnak. Ezen túlmenően van egy gazdag, jól menő középosztály Magyarországon, akikről nem ír senki. Hiába magyaráznak össze-vissza arról, hogy ilyen nem létezik: menjenek le a Káli-medencébe és vegyék észre, hánymilliós bicikliken túráznak középosztálybeli férfiak és nők tömegei, kabrióznak, isszák a drága bort. Meg kell írni őket: ők adják az ütemet, ők viszik elöre az országot". ${ }^{50}$

$\mathrm{Az}$ értékek olyan társadalom-, illetve kultúrspecifikus eszmei objektivációk, amelyekben az emberek szelektív és értékelő viszonya fejeződik ki meglevő világukhoz, társadalmi és természeti jelenségekhez, egymáshoz, tevékenységfajtákhoz és nem utolsósorban önmagukhoz. Az értékképzet pragmatikus, és normatív folyamat eredménye. Tükröződik benne a társadalmi hovatartozás és az önmeghatározás, ami tárgyiasul elvekben, célokban, az együttélési normákban, választásokban, ítéletekben és döntésekben. ${ }^{51}$

\footnotetext{
48 Váriné 1987.

49 Váriné 1987.

50 MANDINER 2020.

51 Váriné 1987.
}

Mihálffy Balázs agrármérnök, a Magyar Iszlám Közösség alapítója, első elnöke és sejkje, közíró. Mosoly a pokolból című könyvéből származó gondolatokat azért emelem be a dolgozatomba, mert nagyon esszenciálisan és közérthetően fogalmazza meg tapasztalati úton nyert következtetéseit. Utazásai, kalandjai és megpróbáltatásai során, élettörténetek tanulsága szerint a következő értékek fontosságára ébredt rá: tudás, béke, szabad légkör, igény a szépségre, a bizalom, bölcselet, egyszerűség, hit, barátság, szeretet, egészség, természet. A pénzről, a hatalomról és birtoklási vágyról több esetben negatívan nyilatkozik, olyas valamiként, mint ami megzavarja az ember ítélőképességét. Az afrikai árvaházban töltött időből írt történeteiből az emberélet, az altruizmus fontossága köszön vissza. Kalandjaiból megismerhetjük a kairói taxisoför szegénység-értelmezését, aki egy nyomornegyedben élt, egy sírban berendezett otthonban. „Azok az igazi szegények, akiknek nem adatnak meg az ilyen beszélgetések és együttlétek" ${ }^{52}$ Bosznia frontjai és Afrika aranybányái közt, több sorsfordító esemény érzékenyítő hatásáról is beszámol: „Szerencsére figyelmeztetett az élet. Koldus lett belőlem, és ma már máshol, másban látom az élet igazi értékeit. Érték a gondolat, ... gesztus, az érintés, a mosoly, ....kincset ér a szeretet" ${ }^{53} \mathrm{~A}$ betegség sorsformáló hatásáról így ír: „egész addigi gondolkodásom átértékelődött, az értékrend, amelyben nevelkedtem elveszttette hitelét,... nem tudtam hinni többé a jó és a rossz kategóriájában". ${ }^{4}$ Végül könyve utolsó gondolata: „Itt az éhhalálhoz közel a dögrováson túl, ahol nincs mit veszteni, ki kell mondani a lehető legfélelmetesebbet: csak a szeretet menthet meg minket". ${ }^{55}$

Egy személy számtalan beállítódással (attitűddel) rendelkezhet, de személyes valóját, énazonosságát, identitását csak néhány centrális értékkel való azonosulása fejezheti ki. Ugyanez vonatkozik a társadalmi csoportokra, sőt népekre, nemzetekre is. ${ }^{56}$

Végül a multikulturális zsidó családok gyermeknevelésben tükröződő értékeit szeretném összefoglalni egy korábbi tanulmányomból kiemelve az ide vonatkozó részeket.

Antropológiai kutatásomban olyan izraelimagyar vegyes családok életét és gyermeknevelési

\footnotetext{
52 Mihálffy 2014:221.

53 Mihálffy 2014:242.

54 Mihálffy 2014:26.

55 Mihálffy 2014:299.

56 Váriné 1987.
} 
szokásait figyelem meg, akik hosszabb-rövidebb ideig élnek Magyarországon. A családok belső életének, müködésének és értékrendjének, világfelfogásának megismerésére fókuszáltam. Tanulmányomban a résztvevő megfigyelés és interjú módszerének alkalmazásával szerzett empirikus tapasztalatokon keresztül ismertettem a családdá és közösséggé alakulás során megteremtődő szociokulturális metszéspontokat. Megjelenik a párválasztás motivációinak kérdése, ill. azok a tényezők - mint a valláshoz, Izraelhez való viszony -, amik meghatározzák a vegyes családok tagjainak identitását. Jelen írásomban csak arra térnék ki röviden, hogyan hat ez gyermeknevelési elképzeléseikre, milyen viselkedési mintákat, kulturális, vallási szokásokat - miért és hogyan - igyekeznek megőrizni, és milyen értékek mentén kívánják nevelni gyermekeiket. A gyermeknevelés, a szocializáció elsődleges közege a család. Erikson szerint: A szocializáció, enkulturáció a kultúra integrálásának legfőbb eszköze, lehetővé teszi a családtagok egymáshoz, a gyermekekhez és a közösséghez, a szélesebb értelemben vett társadalomhoz való kapcsolódását, és megteremti az alkalmazkodás belső feltételeit. ${ }^{57}$ Azonban a vegyes kultúrájú családok esetében a speciális szocializációval kapcsolatban felmerül a kérdés, hogy melyik közeghez való alkalmazkodást tanulja, gyakorolja be a gyermek a nevelés hatására, az anya vagy az apa mögött álló komplex világhoz kapcsolódik? „Két nagyon különböző irányba nem mehetsz a gyerekkel” - fogalmazta meg egyik interjúalanyom.

A gyermekben, aki két vagy több nyelvi és kulturális közegben nevelkedik, „kulturális érzékenység" alakul ki, a többnyelvű gyermek identitása sem az anyáéval, sem az apáéval nem azonos, otthon mozog mindkét kultúrában, ilyen értelemben tehát multikulturális identitással létezik.

Óhatatlanul megtörténik, ha a gyereknevelés gyönyörűségeiről és borzalmairól esik szó az anyák közt, hogy szembeállítják egymással az általuk „izraelinek” és „magyarnak” nevezett „nevelési stílust”, előzőt többnyire az apa, utóbbit az anya képviseli és ez sok vitára ad okot.

„Én próbálom a nevelést nem poroszosan azért, a magyar anyák a gyereknevelésben kevésbé megengedőek, látom magamon és látom a gyerek reakcióját, hogy ha keménykedek és kiabálok. Az apja meg teljesen más, tipikus izraeli, hogy: jaj, gyere, nyunyu, de csinálj, amit akarsz";

„Azt borzalomnak tartom, hogy éjfélkor dőlnek ki a gyerekek az ágyba, nem tartom helyesnek, ami

57 Erikson 1991:396-404.
Izraelben megy, mint gyereknevelés, hogy: majd a katonaság megneveli őket”; ,azt gondolom, hogy egy alapszintü fegyelem azért kell, 11-kor este a gyerekek a játszótéren játszanak azzal én nem értek egyet”; ,ha a végeredményt nézzük, akkor a magyar nevelés sem a legjobb... mert mi meg tele vagyunk önbizalom-hiánnyal”; „Kint (Izraelben) liberálisabb is a nevelés, megengedőbb, vannak ennek jó oldalai is, tehát, hogy a kreativitást azt támogatják. Nálunk ugye a porosz nevelési rendszer ezt elnyomja, erre mondaná azt a férjem, hogy több zseni jön ki abból az országból pont ezért, az egyetemen is jobban teljesítenek".

Nagyon is összecseng és egyértelműen elutasító, elhatárolódó a magyar anyák véleménye az Izraelben tapasztalható gyermeknevelésről, melyet túlzottan megengedőnek, szabadelvűnek, elkényeztetőnek találnak. Ilyen értelemben izraeli oldalról nézve a magyar anyákra jellemző a ,jiddise mame" fogalom, ami a gyermek túlszabályzását, kontrolálását és a szigorúságot jelenti.

$\mathrm{Az}$ a tény, hogy belátják a megengedőbb nevelés pozitív oldalát is, miszerint a „kreatívok lesznek és sok önbizalmuk lesz", valamint képesek visszareflektálni az általuk alkalmazott módszer gyengeségeinek következményeire, „mi meg tele vagyunk önbizalom-hiánnyal”, jó lehetőség ez, hogy a módszerek előnyeit és hátrányait mérlegelve harmonizálják módszereiket.

„Az adaptáció értelmében az ember úgy válik egy kultúra és társadalom tagjává, hogy a gyermekkortól kezdve átveszi az adott kultúra mintázatát." 58 Hogy megtudjuk, szándékuk szerint mi az, amit át akarnak örökíteni, arról kérdeztem a szülőket, milyen értékek átadását tartják egybehangzóan fontosnak a gyermeknevelési gyakorlatuk során? „A vallási értékeket, azt nem nyomjuk annyira, a lényeg az, hogy elfogadó, kedves aranyos szerető, persze beilleszkedni tudó legyen. Tartsa meg a másságát”; „Az első, hogy elfogadásra próbálom nevelni őket”, „becsületesség, a „színház, film, zene és könyvszeretetet”, cél, hogy „nyitott ember”, „világpolgár legyen” gyermekük a jövőben. Megfigyeléseim szerint is igyekeznek bemutatni, átadni gyerekeiknek a tolerancia és a nyitottság szemléletét, a meséken, játékokon keresztül is. Például van olyan család ahol a „Gólya-gólya gilice” kezdetű mondókát kétféleképpen éneklik, egyszer a magyar gyerek, egyszer a török gyerek gyógyítja.

„Az már egyértelmü, hogy egy konkrét valami domináns identitást nem akarunk a gyerekbe

58 Somlai 1997:84. 
beleoltani... legyen tisztában a származásával, a gyökereivel, a kultúrájával, tudja azt, hogy magyar, hogy zsidó, hogy romániai, tudja, értékelje, és elhelyezze... multikulti style-ban nevelünk”; „Szeretném, hogy minél több nyelvet tudjanak, magyar, héber, angol, és utána jöhet még egy-két nyelv”; „A gyerek tanuljon meg akár ezer nyelven, minél több nyelven, mert akkor bármerre megy, meg tudja magát értetni, akkora pozitívum, az fontos".

A multikulturális neveléssel erősíteni szeretnék a minél összetettebb identitás kialakulását. Oktatási, nevelési intézmények választásánál tehát előnyt jelentenek a többnyelvű óvodák, iskolák és igény szintjén megfogalmazódó sajátosság, hogy „nagyon európai, de mégis zsidó" legyen. A közösségben tapasztalt interakciókon, beszélgetéseken keresztül kirajzolódott mi az a „kulturális csomag”, melyet ezek a családok gyerekeiknek át kívánnak adni. Fontos számukra az elfogadás, tanulás, tudás, nyelvtudás.

$\mathrm{Az}$ elfogadás fontosságát példázza a kutatási naplómból származó idézet, melyet egy beszélgetés alkalmával jegyeztem le: „Mert ha zsidóként nagyon érdekelnek a zsidók problémái, de egyébként undorodom a cigányoktól, akkor az nem nevezhető elfogadó magatartásnak. Mert a tolerancia azért alapvetően univerzális”. Fontosként számon tartott értékek közé tartozik a nyelvtudás, mely lehetőséget teremt a gyermekeknek más gondolkodási struktúrákban való közlekedésre, és szükséges is, hogy a tágabb család mind két oldalával tudjanak kommunikálni. ${ }^{59}$

$\mathrm{Az}$ értéktudatosság, a határozott értéktudat kialakulása sohasem izolált folyamat, hanem olyan, amely kéz a kézben halad a személy önismereti és társadalomismereti igényének fejlődésével és ez igény kielégítésével. $\mathrm{E}$ tudatos reflexivitás része az is, hogy az ember igyekszik megismerni, milyen a viszony a közösség ideális értékei és a kialakult gyakorlat között. A valóságos értékek mindig valamilyen függvényviszonyban értelmezhetők. Az értékeket minden felnövekvő nemzedék egybeveti saját mindennapi létének és környezetének a tapasztalataival, saját vágyaival, vélt vagy valós érdekeivel és szükségleteivel. ${ }^{60}$

Akárhogy is nézzük, az értékeink és életünk értelme komoly kapcsolatban van egymással, mind az egyén, mind pedig a csoportok, társadalmak, kultúrák szintjén. Az értékek és szükségleteink, valamint érdekeink sokrétegű összefonódása egy úfajta ön-tudatosságot kíván meg tőlünk. A civilizáció

59 Buk 2020.

60 Váriné 1987. hajnalán az ember talán szükségleteihez igazította értékeit, a kapitalizmusban úgy tűnik, emberek tömegei az érdekeikhez igazítják értékeiket, azonban ez nem tűnik fenntartható stratégiának. Mindig voltak, vannak lokális kiscsoportok, akik törekedtek, törekednek a holizmusra, talán eljött az ideje, hogy megpróbáljuk az értékeinkhez igazítani az érdekeinket, ezen keresztül szükségleteiket is. Amikor gyermekeinkre gondolunk, akkor látja a szívünk és az elménk legtisztábban, hogy hol vannak a prioritások. Gyugyu vagy Tomoceuszkakatiti? Esetleg kereshetünk más alternatívákat... Az értékek témájának boncolgatását, kutatását, az erről való gondolkodást nem lehet befejezni, csak pillanatnyilag abbahagyni, talán azért mert valami nagyon mély a létezésünk lényegére vonatkozó kérdésre való választ szeretnénk megragadni álltaluk.

\section{Felhasznált szakirodalom}

Balázs Gábor 2017 Harari, a vallás és a kognitiv diszkomfort. Szombat, 2021. január 10. https:// www.szombat.org/archiv?q=Bal\%C3\%A1zs+G \%C3\%A1bor\&y=2017\&mo=7

BIBLIA, GALATÁKHOZ, 5.14

https://hu.wikipedia.org/wiki/ Felebar\%C3\%A1ti_szeretet\#cite_note-2

Buk Kriszta 2020 Mítosz vagy realitás ma a zsidó család. Közelítések 1-2. http://epa.oszk. hu/02100/02184/00016/pdf/EPA02184_ kozelitesek_2020_01-02.pdf

Csepeli György 2020 Ember 2.0: A mesterséges intelligencia gazdasági és társadalmi hatásai. Budapest, Kossuth Kiadó.

Eger, Edith Eva 2020a $A$ döntés. Budapest, Libri Könyvkiadó.

Eger, Edith Eva 2020b Az ajándék. Budapest, Libri Könyvkiadó.

Erikson, E. H. 1991 Az életciklus: az identitás epigenezise - A fiatal Luther és más irások. Budapest, Gondolat.

Fiala, Jaroslav 2017 Önkizsákmányolásunkról. Ford. Zsámboki Miklós. Kettős Mérce, 2017. június 25 . https://kettosmerce.blog. hu/2017/06/25/onkizsakmanyolasunkrol

Han, Byung-Chul 2020 Pszichopolitika. Budapest, Typotex.

Hankiss Elemér 1977 Érték és társadalom. Tanulmányok az értékszociológia köréböl. Budapest, Magvetö. 
Hankiss Elemér 2004 Társadalmi csapdák és diagnózisok. Budapest, Osiris Kiadó.

Hankiss Elemér 2005 Az ezerarcú én. Budapest, Osiris Kiadó.

Hankiss Elemér 2006 Félelmek és szimbólumok. Budapest, Osiris Kiadó.

Harari, Yuval Noah 2015 Sapiens - az emberiség rövid története. Budapest, Animus Kiadó.

Kötter Tamás 2020 Nevezhetjük akár konzervatív forradalomnak is. Mandiner. https://mandiner. hu/cikk/20201114_kotter_tamas_interju?fbcli $\mathrm{d}=$ IwAR2uTC1eMQNMYB9PiRMSAytnVXj nWA_HSN3ehCEb-0Cv31K8hcjZizyn7-4

Laár András 2020 Ugyanaz az ÉN néz ki mindenkinek a szemén. Hajnali interjú. On-line:

https://www.youtube.com/watch?v=GdhSyRRxM TQ\&feature=share\&fbclid=IwAR2hKL43_0Q Bm9dP0_MCqmSPENHc6Np_6ce0z9YDGZfYk-wxgAv-o2lMe8

Marosán György 2007 A proszociális értékek evolúciója a játékelméleti kísérletek tükrében. Közgazdasági Szemle, LIV. évf., július-augusztus (716-733.) http://epa.oszk. hu/00000/00017/00139/pdf/06szmarosan.pdf

Mihálffy Balázs 2014 Mosoly a pokolból. Budapest, Noran Libro.

Prazsák Gergő 2015 Marginális csoportok értékrendszerei. Kultuira és Közösség, IV. folyam VI. évfolyam 2015/I. szám, http://www. kulturaeskozosseg.hu/pdf/2015/1/09.pdf

Somlai Péter 1997 Szocializáció - A kulturális átörökités és társadalmi beilleszkedés folyamata. Budapest, Corvina.

Szakács Ferenc Dr. 1985 Személyiséglélektani szöveggyüjtemény. Budapest, Tankönyvkiadó.

Váriné Szilágyi Ibolya $1987 \mathrm{Az}$ ember, a világ és az értékek világa. Budapest, Gondolat Kiadó. https://regi.tankonyvtar.hu/hu/tartalom/tkt/ szocialpszichologia/ch05s04.html 